\title{
Sixteen new records for the flora of Lebanon
}

\author{
Khodr Addam*, Mounir Bou-Hamdan, Nisreen Sabbagh \\ Integrative and Environmental Research Center, AUL Beirut, Lebanon
}

Received: August 06, 2020

Revised: November 17, 2020

Accepted: November 18, 2020

Published: November 23, 2020

*Corresponding author:

Khodr Addam,

E-mail: draddam@hotmail.com KEYWORDS: Taxonomy, biodiversity, flora, Lebanon, Mediterranean, new records

\begin{abstract}
Significant new species that belong to diverse genera and families were recorded to exist in Lebanon during our continuous non-stop field survey all over the country. The authors gathered some exceptional taxa from distinctive locations and habitats of the country, which were not reported so far in the flora documentation with the exception of Quercus libani, that is regarded as a very atypical species (for Lebanon) discovered for the first time after Post in 1932. The current paper deals with the records Anchusa milleri Lam. ex Spreng, Bassia hyssopifolia (Pall.) Kuntze., Eminium heterophyllum (Blume) Schott., Euphorbia prostrata Aiton, Euphorbia serpens Kunth, Hypericum olivieri (Spach) Boiss., Kickxia cirrhosa (L.) Fritsch., Lamium macrodon Boiss. \& A.Huet, Onosma fruticosum Sm.lder, Plantago crypsoides Boiss., Platanthera holmboei H.Lindb., Potamogeton perfoliatus L., Quercus libani G.Olivier, Rhamnus kurdica Boiss. \& Hohen., Tulipa biflora Pall. and Xanthium strumarium subsp. sibiricum (Patrin ex Widder) Greuter. The plants were photographed, collected, dried and herbarium specimens were prepared and deposited in K. Addam's Herbarium AUL University (Lebanon). Their taxonomical and ecological characters as well as their geographical distributions were exhibited. New Taxa (representing 14 genera in 12 families of flowering plants) were recognized with the reference of different floras and recent literature for their authentication. The present study also files them with updated nomenclature, descriptions, and notes on phenology and images for their easy identity.
\end{abstract}

\section{INTRODUCTION}

Flora is an assembly of native plants in a bionetwork of a geographical area. Floral characteristics and plant biodiversity are very imperative for mankind because they support life in the biosphere at all probable spatial scales. They are of great prominence in local and global energy balance since they strongly impact soil properties and serve as wildlife habitat. They can flourish sometimes in biodiversity hotspots, which are earth's most biologically rich yet vulnerable terrestrial regions [1]. Myers recognized the Mediterranean basin as one of the world's "hotspots" comprising unique and high percentages of the world's biodiversity in relatively small areas. Many reasons have been put forward to explicate such natural wealth, but for our purposes here, it is vital to recognize the outcomes of the geographic and climatic variations in the nature of the present biodiversity of the Mediterranean basin [2]. The Flora of the Mediterranean encompasses more than 25000 species of flowering plant, this is nearly $10 \%$ of all notorious flowering plant species on earth, although the land area of the basin is only $1.5 \%$ of the earth's land surface [3]. The East Mediterranean, precisely the Levantine uplands [4] where Lebanon is included in this basin, is considered as one of the most stirring spots of conservation in the world. [5] In a fairly small land area, Lebanon embraces an extremely high level of biodiversity. By setting Lebanon in its universal context, the importance of this richness in its fauna and flora can be better valued. In fact, what can seem common at a local level can be highly scarce at global one [6]. The country makes up only $0.007 \%$ of the world land surface area but is a shelter to $1.11 \%$ of world plant species. Lebanon's floral diversity is one of the premiers in the Mediterranean (more than 3150 plant species), a territory that is considered to be one of the most biologically diverse in the world. About $12 \%$ of plant species in Lebanon are endemic and this is measured as a high rate of endemism. Lebanon is also home to nine nature reserves, three biosphere reserves, one UNESCO World Heritage Site, and 15 Important Bird Areas (IBAs) recognized by Birdlife International [7][8]. This very rich and matchless biodiversity of Lebanon is chiefly due to its site in the far eastern end of the Mediterranean Sea, mountainous topography (altitudinal diversity), and the great variety in its climatic conditions. This sundry topography gives rise to many microclimates, favorable to the occurrence of many plant and animal species and communities $[9,10]$. Geographically, Lebanon, a narrow strip of territory nearly 160 miles long and 20 to 50 miles wide, is a mountainous country situated on the eastern shore of the

Copyright: () The authors. This article is open access and licensed under the terms of the Creative Commons Attribution License (http://creativecommons.org/licenses/by/4.0/) which permits unrestricted, use, distribution and reproduction in any medium, or format for any purpose, even commercially provided the work is properly cited. Attribution — You must give appropriate credit, provide a link to the license, and indicate if changes were made. 
Mediterranean Sea. It has a narrow coastal plain that vanishes in some places. The snow-capped Mount Lebanon range rises from the coastal plain and is disjointed from the Anti-Lebanon Range to the east by the prolific Bekaa Valley. The mountains are craggy and are mostly made up of Jurassic and Cretaceous limestone and sandstone [11].

Lebanon is the treasury of wonders for wild herbs. It still surprises us every year while continuing our fieldwork searching for wild herbs that grow on many of its benevolent lands. It unveils new plants that are added to the abundant stock of herbal treasures and embraced in its wonderful Middle Eastern environment. Most of the new discovered herbs were found in Anti-Lebanon Range and Bekaa Valley. Many scientists expounded on the Lebanese flora such as Tohme and Tohme, Haber and Haber, Mouterde, Post, Dinsmoreand, Addam, Bou-Hamdan and others. [12-24]. In 2014, and according to Tohme and Tohme's calculations, the overall number of Lebanese plants (trees and ferns included) was 2,612 species, 770 genera, 155 families, and 58 [14] unfound species by the authors which have been mentioned to subsist in Lebanon previously by Mouterde P. [15] and Post G. [13] Actually, there are no meticulous data about the factual number of existing flora in Lebanon. This is because some authors and researchers cited many species and number of floras in their books without any official (peer reviewed journals) publications or even any deposited specimens for these species in any herbarium in Lebanon to ascertain academically that they were found; we have only books with pictures without academic pieces of evidence or value. The second reason is the publications that have been completed by scientists from other countries and we found by chance during our search in Research Gate for literature review. Besides, few are the professional taxonomists in the field of botany in Lebanon, those researchers that have a specialized fieldwork and skills in the Lebanese flora. This is one of the most arduous works in the field of Botany. It needs wide knowledge, fervor, persistence, determination, and love to nature. During our very extended journey in the field work (22 years), we (K Addam \& M Bou-Hamdan) found more than three hundred new records of flora that strive normally in Lebanon. We commenced publishing them at 2013 and activated our process every year more and more. We collect these species, varieties, subsp, hybrids and formas and deposit them as dried samples vouchers specimens in K. Addam's Herbarium Arts, Sciences and Technology University in Lebanon AUL in which they are published gradually. These new discovered floras were not found before because of the occurrence of extremely difficult environmental conditions as they grow in regions such as high mountains, rocky territories, rural places and the perilous political conditions predominantly reaching the Syrian borders where the war is in action. Much of the border lies on far-off and mountainous terrains that make access challenging and threatening [25].

Fifteen sporadic and new recorded flora were found primarily in Lebanon including Anchusa milleri, Bassia hyssopifolia, Eminium heterophyllum (Blume) Schott., Euphorbia prostrata Aiton, Euphorbia serpens Kunth, Hypericum olivieri (Spach) Boiss., Kickxia cirrhosa (L.) Fritsch., Lamium macrodon Boiss. \& A. Huet, Onosma fruticosum Sm.lder,
Plantago crypsoides Boiss., Platanthera holmboei H.Lindb., Potamogeton perfoliatus L., Quercus libani G.Olivier, Rhamnus kurdica Boiss. \& Hohen., Tulipa biflora Pall. and Xanthium strumarium subsp. sibiricum (Patrin ex Widder) Greuter.Their locations were dispersed from south Lebanon to the North, but most of them were found in the northeast.

\section{MATERIALS AND METHODS}

Tens of expeditions took place to unusual places of Lebanon from its North to South and East, but mainly, a lot of them were found in the Northeast. Most of the newly found species were discovered and registered in countless places in Lebanon between the years 201 land 2019 and were followed and observed. Plants were collected, dried, mounted, and deposited in AUL University - Lebanon at K. Addam Herbarium. All the plants were found and pictured during flowering time by $\mathrm{M}$. Bou-Hamdan except Onosma fruticosum Smlder. which was found and pictured by K. Addam and Platanthera holmboei H. Lindb. by Khaled Taleb. These species are incorporated neither in books nor in relevant publications whereby literatures have been published before. Most of these species are very rare in Lebanon and very tiring to discover, but they are straightforwardly distinguished and detected during the fieldwork especially at grave places at the border with Syria where a state of war is going on till now.

\section{RESULTS}

In this study, Anchusa milleri, Bassia hyssopifolia, Eminium heterophyllum (Blume) Schott., Euphorbia prostrata Aiton, Euphorbia serpens Kunth, Hypericum olivieri (Spach) Boiss., Kickxia cirrhosa (L.) Fritsch., Lamium macrodon Boiss. \& A. Huet, Onosma fruticosum Sm.lder, Plantago crypsoides Boiss., Platanthera holmboei H. Lindb., Potamogeton perfoliatus L., Rhamnus kurdica Boiss. \& Hohen., Tulipa biflora Pall. and Xanthium strumarium subsp. sibiricum (Patrin ex Widder) Greuter. were discovered, identified, and examined for their taxonomic, morphologic and phenological attributes and added to the Lebanese flora for the first time. Only Quercus libani G. Olivier was reported to be found by George Poste in 1933 and since then, no one has reported to find this species in Lebanon. Even Mouterde in 1966 did not find it. He pondered how it was called Libani, and it was found by him only in the North Lattakia forest in Syria during his whole field work for about 35 years in Lebanon. Quercus libani was discovered in two places in Lebanon after 97 years.

\section{DESCRIPTION, HABITAT, LOCATION, PHENOLOGY, DATE OF DISCOVERY AND SPECIMENS}

\section{Anchusa Milleri Lam. ex Spreng (Boraginaceae)}

Description: Annual plant, 10-50 cm high; simple or branched stem, procumbent; leaves alternate, oblanceolate to oblong, entirely coated with short hairs and long bristles, smooth margin; apex obtuse to acute; base attenuate; sessile upper leaves; 
inflorescence, raceme-like, and lax in fruit; hermaphrodite, flowers bracteate, and pedicellate. Bracts, foliose, sessile; pedicel 3-8 mm, elongate in fruit; calyx 5-7 mm, divided almost up to base; lobes, linear, and not accrescent in fruit; corolla $1-1.3 \mathrm{~cm}$, white or pinkish; tube 7-9 mm, straight; scales, $0.5 \mathrm{~mm}$, inserted at the corolla-throat, exserted, oblong, velutinous, the tips curved outwards; limb 4-5 mm broad, somewhat zygomorphic; lobes $1.5-2 \mathrm{~mm}$, mostly obovate; stamens inserted at the middle of the tube in 2 series of 2 and 3 ; anthers $1 \mathrm{~mm}$, oblong- elliptic, obtuse; glabrous ovary; style 2-2.5 mm, slender, glabrous; stigma 2-lobed, fruits and pods 4 nutlets, 3.5-4 x 2-2.5mm, erect or lightly oblique; flat inner face, convex outer face, and reticulateribbed; smooth, yellowish-brown, glabrous ribs (Figure 1: [26].

Habitat: Cold semi-arid climates are typified by rainless summers and wetter cold winters (temp - 1 to $36^{\circ} \mathrm{C}$ ) with some snowfall (annual rainfall rate $150-450 \mathrm{ml}$ ), high elevations: $700-1200 \mathrm{~m}$ (up to $1500 \mathrm{~m}$ ). The species are distributed on stony grasslands, dry rock-strewn slopes, bush clearings, tundra (absence of trees) in mountains with very dry soil in summer and semiwet during blossoming.

Location: Qaa, Lat 34.328944. Long 36.494538, Alt: 778m. 19/ VIII/2018. (Figure 18).

\section{Phenology and Date of discovery: VII-X. 19/VIII/2018.}

Specimen and accession number in K. Addam Herbarium: 1981820-001 (Figure 17:).

\section{Bassia Hyssopifolia (Pall.) Kuntze. (Amaranthaceae)}

Description: Annual plant, commonly up to $1 \mathrm{~m}$ (sometimes taller $1.5 \mathrm{~m}$ ) with plain or branching stems; leaf lower 5-60 mm, 1-3.5 mm wide blades are flat (wilted in age) and linear to lance-shaped; short inflorescence $5-50 \mathrm{~mm}$; bracts +- oblong; narrow spike, occupying the upper stem, filled with flowers (woolly-haired) growing solitary, paired (sometimes in clusters of three); cramped flower with five segments, each of which has a hooked spine at maturity; fruit less than $2 \mathrm{~mm}$ in length, curved spines +-1 mm; dry fruit 1-1.5 mm diam; seed dark brown; taproot with few to several lateral diverged fibrous roots (Figure 2: [27,28]

Habitat: This plant simply grows in alkaline and saline soils. It favors wetland areas and drought disturbed regions such as roadsides and crop fields and even near the seashores next to the garbage. It usually does not have a harmful outcome on local ecosystems. The infestations are seldom acute.

Location: Saida, Lat 33.554696. Long 35.364674, Alt: 3.16m. 30/IX/2016. Mapl

Phenology and Date of discovery: 30/IX/2016.

Specimen and accession number in K. Addam Herbarium: 309165-001 (Figure 17b).
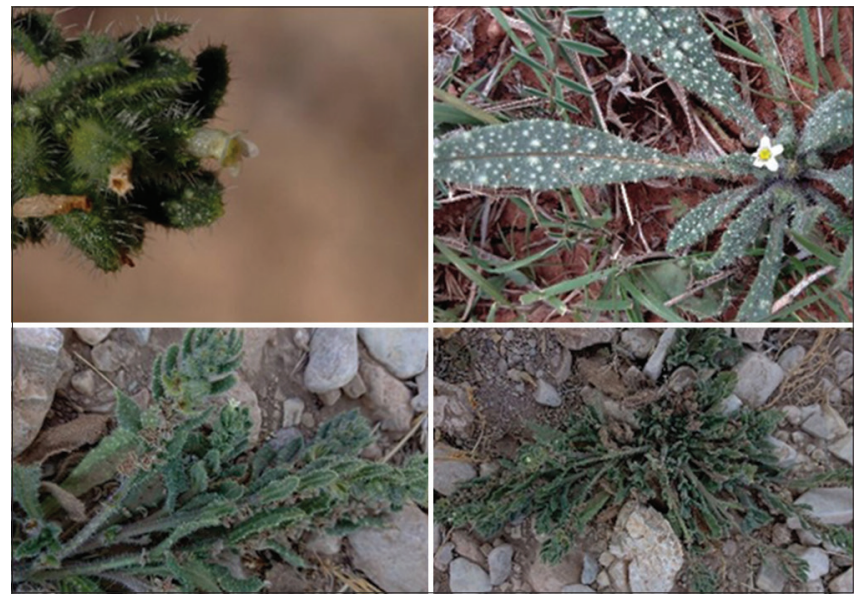

Figure 1: Anchusa milleri

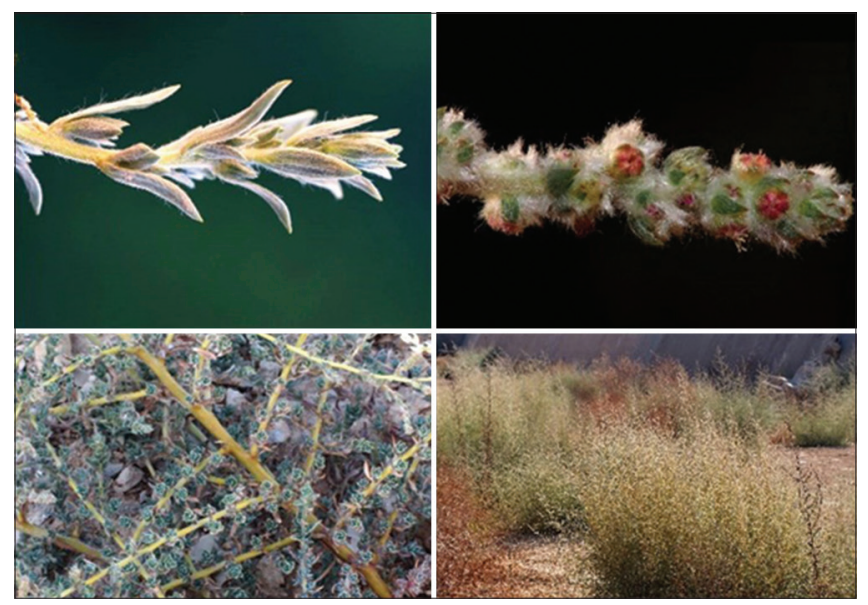

Figure 2. Bassia hyssopifolia

\section{Eminium Heterophyllum (Blume) Schott. (Araceae)}

Description: Perennial plant; medium-sized, seasonally dormant herbs, tuber subglobose. Petiole sheaths relatively long. Leaf 3-6 (-8) grey-green, one or two posterior lobes division, very rarely entire, blue-grey, blade oblong to deeply pedatifid with outermost lobes spiralling on twisted basal ribs, fine venation reticulate; peduncle often impressively stiffened at the apex. Inflorescence, solitary, appearing with leaves. Peduncle, much shorter than petiole of subtending leaf, apex often greatly thickened. Spathe limb interior smooth, not really wrinkled or verrucate.Spadix slender, much shorter than spathe. Spadix appendix smooth; upper staminodes subulate, lower staminodes flattened. Flowers, unisexual, perigone absent. Infructescence borne at or below ground level, berries white to pale lilac, pericarp firm, not juicy; sterile zone between male and female zones enclosed completely with subulate. Seed, obnapiform to subglobose, testa leathery, rugose, with large strophiole, embryo small, elongate, endosperm copious (Figure 3: [29,30].

Habitat: dry to moist substrates, full sun on marginally acidic to alkaline, mountains, grassy areas in garrigue, frequently favors open rocky places in tough environmental factors. It thrives also in resilient seasonal habitats and adapts to a semi-arid 
environment by growing in sandy or stony soil (found also at the border with Syria) between Quercus trees in full sun but not beneath them in the shade, up to $1211 \mathrm{~m} \mathrm{[25].}$

Location: Aarabet Qozhaiya, Lat 34.17498999999999942645. Long 35.56156999999999972317, Alt: 1206.94m. 7/IV/2017 (Figure 18).

Phenology and Date of discovery: IV-V.7/IV/2017.

Specimen and accession number in K. Addam Herbarium: 741710-001 (Figure 17c).

\section{Euphorbia Prostrata Aiton (Euphorbiaceae)}

Description: Monoecious, prostrate, yearly herb with branches up to $20 \mathrm{~cm}$ long, tinted purplish, with abundant adventitious roots; stems with latex; leaves opposite, distichous, simple; stipules triangular, c. $1 \mathrm{~mm}$ long, 2-toothed; inflorescence a terminal or axillary cluster of flowers, called a 'cyathium', on short leafy shoots; cyathia almost sessile, c. $1 \mathrm{~mm} \times 0.5 \mathrm{~mm}$, with a barrelshaped involucre, lobes triangular; glands 4, minute, transversely elliptical, red, with very little pink or white appendages, each involucre inclosing 1 female flower encircled by few male flowers. Flowers unisexual; male flowers sessile, bracteoles hair-like, perianth absent, stamen c. $1 \mathrm{~mm}$ long; female flowers with pedicel c. $1.5 \mathrm{~mm}$ long and reflexed in fruit, ovary superior, glabrous, 3-celled, styles 3, minute, 2-fid (Figure 4) [31,32].

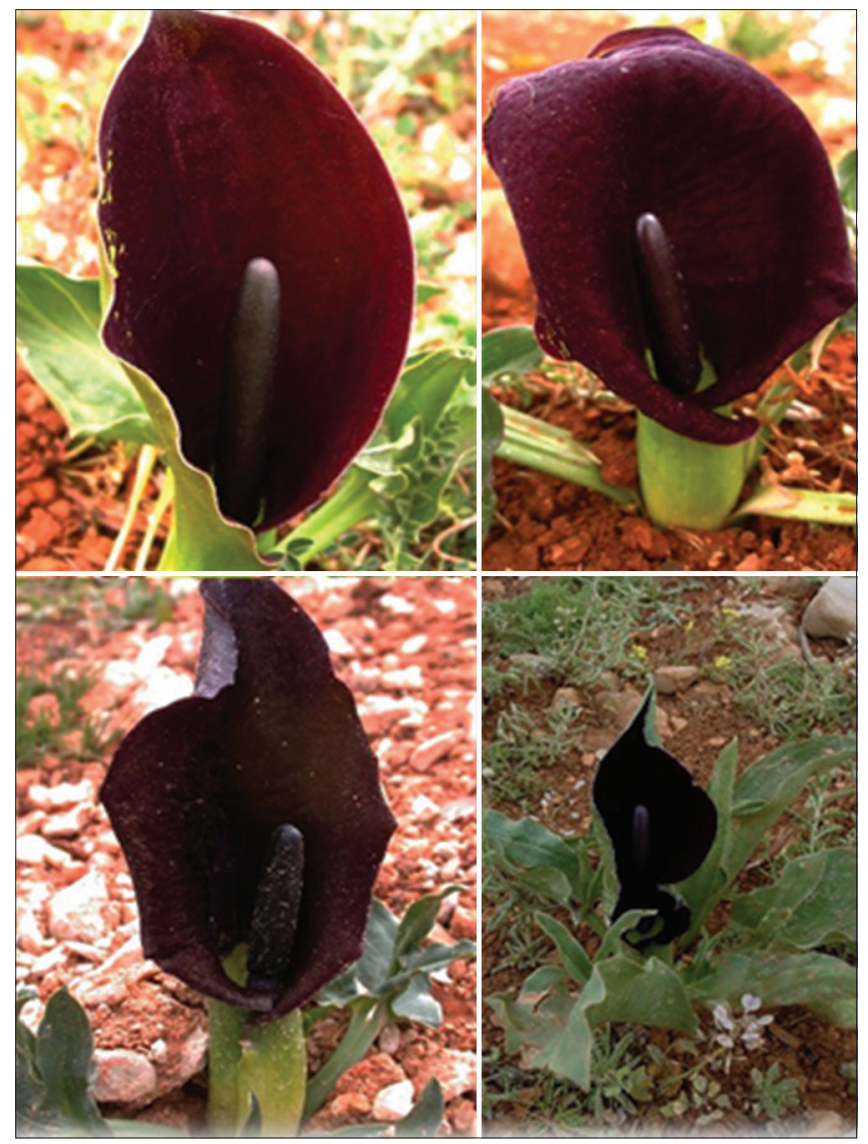

Figure 3:Eminium heterophyllum
Habitat: Mediterranean climate portrayed by a hot, extremely humid summer, pleasurable autumn and spring, and cool rainy winter. $86 \mathrm{~m}$, grows in alkaline and saline soil, favors wetland areas and drought disturbed regions such as roadsides beside the coastlines and garbage.

Location: Beirut, Lat 33.5247097477. Long 35.2938411865, Alt: 78.56m. 30/X/2019.

Phenology and Date of discovery: IX-XI, 30/X/2019 (Figure 18).

Specimen and accession in K. Addam Herbarium: 30101949 001 (Figure 17d).

\section{Euphorbia Serpens Kunth (Euphorbiaceae)}

Description: Annual plant, minute, much-branched prostrate with hairless branches up to $20 \mathrm{~cm}$ long (can reach a length of $65 \mathrm{~cm}$ ), rooting at nodes; leaves $4 \mathrm{~mm}$ long, greyish green without dark spots (later the entire leaf can turn into purplish), simple, lobed or unlobed but not separated into leaflets, opposite, two leaves per node along the stem , broadly ovate to about round, up to, cordate at the base; margin entire; inflorescence, stipules are whitish, connate, wider than long; cyathium 1 per node, white appendages, involucre 0.5--1.5 mm, obconic; glands 4, $<0.5 \mathrm{~mm}$, transversely oblong ; flower terminal or on petite axillary shoots, radially symmetrical, maroon-purple a white, no petals, sepals or tepals in the flower, or they are not clearly present, sexes separate on the same; fruit 3-lobed capsule $18 \mathrm{~mm}$ long, yellowish-green, exserted on a reflexed pedicel (Figure 5) [33,34,35].

Habitat: Same habits as Euphorbia prostrate. In fact, they share the same place.

Location: Beirut, Lat 33.52469326779. Long 35.297277219, Alt: 85.05m. Beirut, Lat 33.528964839. Long 35.2903979399, Alt: 86.01. 30/X/2019 (Figure 18).

Phenology and Date of discovery: IX-XI. 30/X/2019
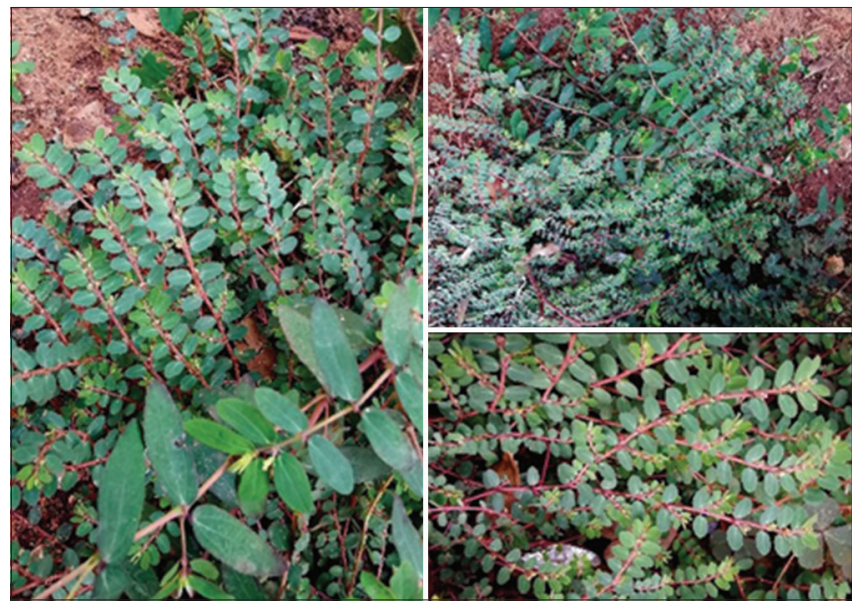

Figure 4. Euphorbia prostrata 
Specimen and accession number in K. Addam Herbarium: 30101949-002 (Figure 17e).

\section{Hypericum Olivieri (Spach) Boiss. (Hypericaceae)}

Description: Perennial herb 10-67 cm , upright, glabrous, branching at base and frequently from all or even most nodes, sterile shoots not noticeable; stem \pm plentiful amber or black gland dots, unclear; internodes $6-25 \mathrm{~mm}$ longer or shorter than leaves; leaves sessile, $8-30 \times 0.5-1.5 \mathrm{~mm}, \pm$ glaucous, spreading, longitudinal lamina, round apex, revolute margin, cuneate base; l-veined; pale laminar glands, numerous; marginal glands not visible; inflorescence about 10 flowers, narrowly pyramidal to cylindric, $15-170 \mathrm{~mm}$ long, with lateral cymules 1-10 (-13)-flowered, recurrently it is up to 6 branches below; bracts and bracteoles linear, entire; flowers $10-15 \mathrm{~mm}$ in diam., with deflexed becoming petals; buds ellipsoid, rounded to obtuse. Sepals equal, free, $1-2.5 \times 0.7-1.5 \mathrm{~mm}$, spathulate or elliptic to oblong, acute; veins three, becoming prominent; margin commonly glandular-denticulate to -fimbriate or with sessile glands, glands black, obconic to ellipsoid, apex eglandular; laminar glands pallid, in 2 or 4 continuous or interrupted lines. Petals bright yellow, not red-tinged, $4-7 \times 2-3.5 \mathrm{~mm}$, obovate, long-unguiculate, apiculate to round, margin black-glandularciliate against apex; laminar glands pale, distal, punctiform. Stamens 35-40, longest $5-7 \mathrm{~mm}$, petals are about equalling; filaments yellow; ovary $1 \times 1 \mathrm{~mm}$, globose; styles $2-3 \mathrm{~mm}, 2-3 \times$ ovary. Capsule 2-3 $\times 3-4 \mathrm{~mm}$, depressed-globose or profoundly sulcate; vittae prominent; valves devided as few- to l-seeded cocci; seeds not seen (Figure 6) [36].

Habitat: Same habits as aforementioned Anchusa milleri.

Location: Makneh, Lat 34.059858. Long 36.196702, Alt:170m. Makneh, Lat 34.060255. Long 36.194601, Alt, 1077m. 16/ VI/2019 (Figure 18).

Specimen and accession number in K. Addam Herbarium: 1661957-001(Figure 17f).

\section{Kickxia Cirrhosa (L.) Fritsch. (Plantaginaceae)}

Description: Annual or perennial plant, $20-50 \mathrm{~cm}$, with lengthy stems, bristling with long, spreading, spreading or climbing hairs, slim, glandular-hair, sometimes rooting at the nodes, leaves alternate, petiole shorter than limb, tiny, lanceolate-hasted, acute, entire, somewhat twisted, shaggily hairy, short-stalked; flowers very small $4-6 \mathrm{~mm}$, solitary at the axil of all leaves on capillary peduncles much longer than they are, divariate, arched at the apex, hairy calyx, whitish stained mauve, or with violet blue upper lip, yellow lower lip and a purple-spotted palate 11$15 \mathrm{~mm}$; spur intensely curved; capsule globular, outdoing the calyx, opening with two opercules, exceedingly tuberculous seeds (Figure 7) [37].

Habitat: Pine forests in the shade and open places, riversides amid the rocks, field margins, uncultivated roadsides, hill slopes, and waste ground.
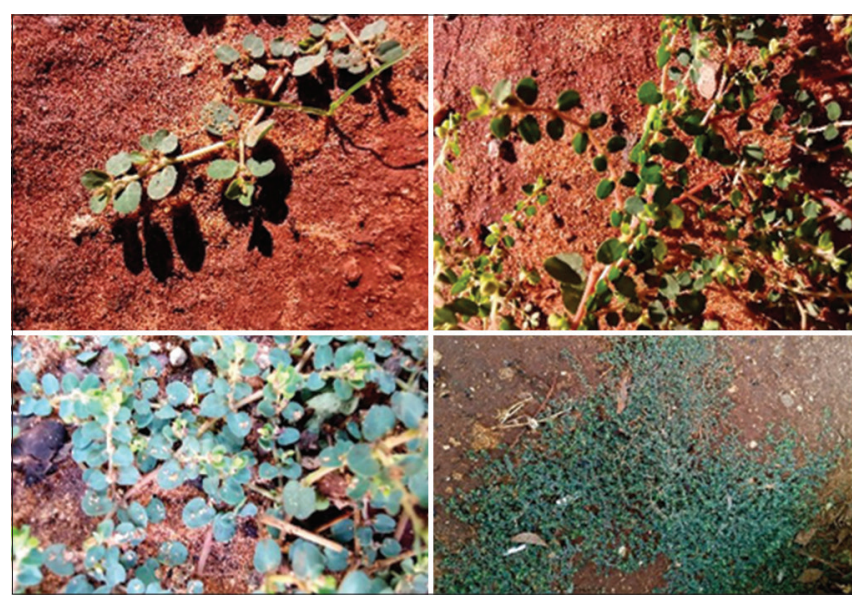

Figure 5: Euphorbia serpens
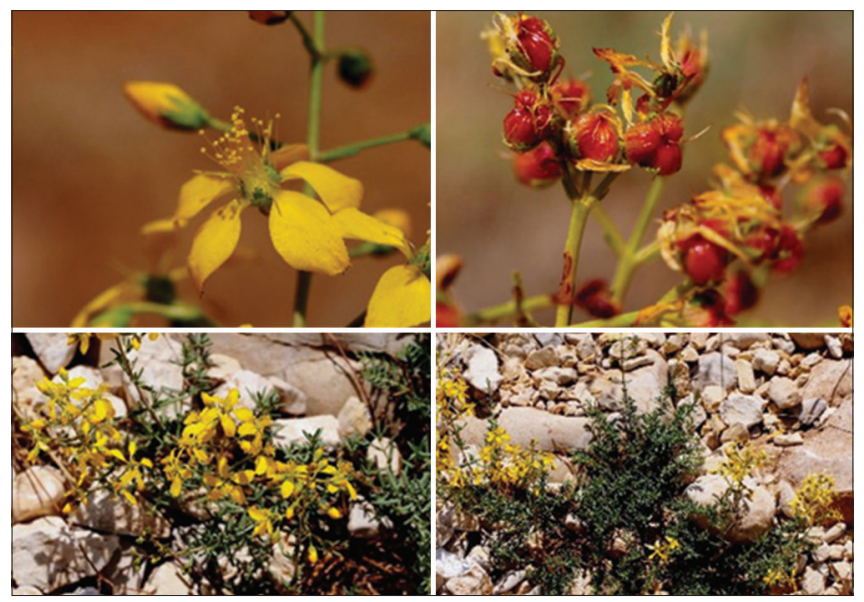

Figure 6: Hypericum olivieri

Location: Gharife -Nahr El Heri, Lat 33.647059. Long 35.538060, Alt: 569m Gharife -Nahr El Heri, Lat 33.648389. Long 35.538506, Alt: 566m. 9/6/2019 (Figure 18).

Phenology and Date of discovery: VI-VII. 9/6/2019.

Specimen and accession number in K. Addam Herbarium: 941889-001 [Figure 17g].

\section{Lamium Macrodon Boiss. \& A. Huet. (Lamiaceae)}

Description: Annual plant, pubescence, multicolored, small size, $5-15 \mathrm{~cm}$; stem square coarsely surfaced pairs of leaves, often with outstanding patterns or variation; lower leaves petiolate, ovate, crenate, subtruncated at the base; flower $1-3$, very close, densiflores, double-lipped (obtuse upper lip) in a wide more developed range of colours, sessile, amplexicaules surrounded by pseudo-whorls; calyx, hirsute, with lanceolate teeth at the base, prolonged with a setose ridge, twice longer than the tube, at the end more or less spread out; corolla pink with no pubescent tube inside; nucules reticulate of white (Figure 8) [38-40].

Habitat: The climate of the area is depicted by cold winters with frequent precipitation as snow (annual rainfall rate $1200 \mathrm{~mm}$ ), 
rigorous summers with extended physiological drought, prefers full sun, on slightly acidic to alkaline, rocky mountains, an open rocky places in tough environmental conditions. Location: Jabal Mresti, Lat 33.621345. Long 35.665803, Alt: 1664m. (Figure 18).

\section{Phenology and Date of discovery: 22/V/2011.}

Specimen and accession number in K. Addam Herbarium: 2251162-001 (Figure 17).

\section{Onosma Fruticosa Labill (Boraginaceae)}

Description: Perennial, small erect or suberect shrubs (few parts drying back annually, usually the short in- florescence shoots only) or subshrubs with minute, narrow leaves, reminding somewhat of Lavandula leaves and the terminal one or two flowered (very rarely three-flowered) inflorescences, as well as the indumentum of stellate and tiny simple hairs; stem, indumentum of long setae and short hairs \pm appressed to patent, tubercles bulged, without or with few rays on the periphery; leaves (on full grown plants in nature), narrow, obovate or lanceolate, strongly enrolled at the margin, and look fascicled on the young shoots in the axils of the leaf; sepals, narrow lanceolate to narrow triangular, free up to the base, little enlarged in fruit indumentum, outside appressed to patent; tubercles of long setae with our without rays, short hairs
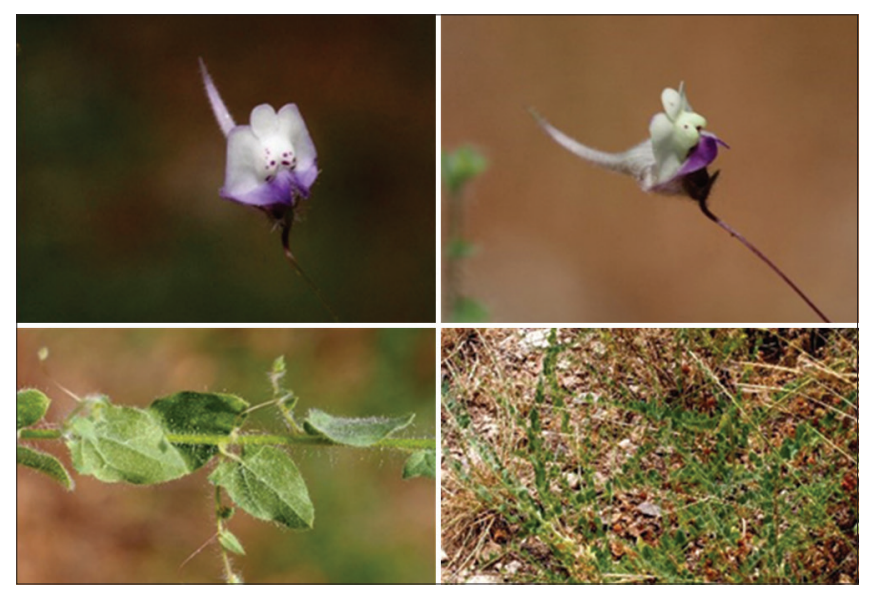

Figure 7: Kickxia cirrhosa
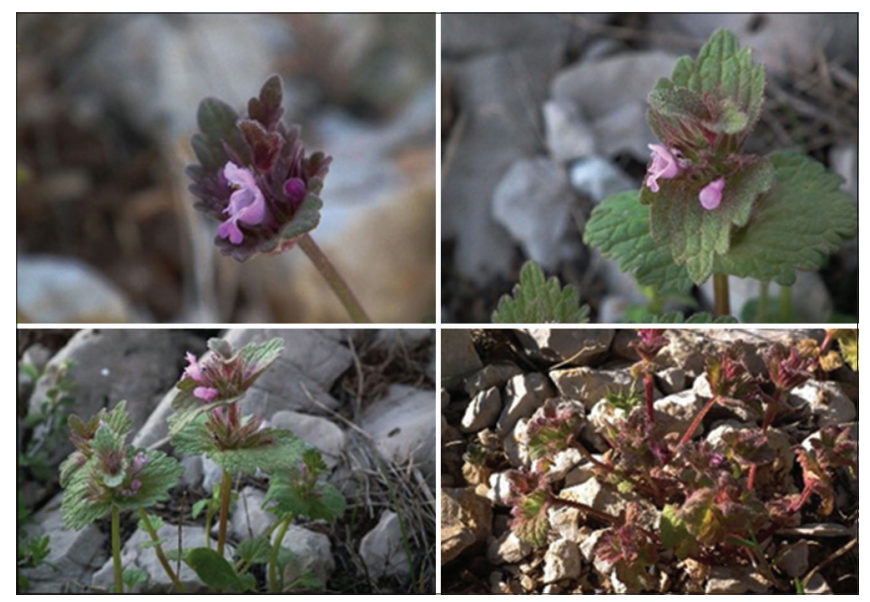

Figure 8: Lamium macrodon in-between, whitish-bearded at the margin in the lower $1 / 2-2 / 3$, inside short hairs up to the base, hairs become longer in the upper $2 / 3$, dense toward the tips; corolla dark yellow, becoming red or orange brown at the mouth during anthesis, fading bluish when wilting and drying up papillose from outside, hairy on the tips and along the back of the lobes, sparsely hairy along the dorsal veins of the tube, from inside smooth, except for the slightly papillose tips; corolla filament-tube is approximately has the same length as the free parts of the filaments; anthers, strongly attached side by side at the very base, more or less sticked relatively together laterally, gradually tightened to the tip, nutlets ovoid, regularly one half a bit smaller, widest near the middle or barely below, no shoulders, apex actively rounded, ventral edge a little protruding, rounded, not sharp (Figure 9) [4l]

Habitat: dry fresh calcareous basic-rich soils, pine forests but it grows in direct sunlight and never beneath the trees, poor meadows, open rocky place at high altitudes (1052 m).

Location: Botmeh, Lat 33.3945338. Long 35.3824061, Alt: $1072 \mathrm{~m}$. Botmeh, Lat 33.3946.531. Long 35.3824.616. Alt: $1055 \mathrm{~m}$.Botmeh, Lat 33.3950383. Long 35.3819691, Alt: 1052m. (Figure 18).

Phenology and Date of discovery III-V: 26/IV/2013.

Specimen and accession number in K. Addam Herbarium: 2941320-001 (Figure 17i).

\section{Plantago Crypsoides Boiss. (Plantaginaceae)}

Description: Annual, hairy plant, $5 \mathrm{~cm}(\mathrm{or}+)$; leaves rosette, linear, divided, dissected once, dentate (paired teeth), smooth, acuminate at the apex; Inflorescence equal or shorter than subtending leaf; spike raceme; flower tetramerous, bract $(3.5 \mathrm{~mm}$ or-) shorter than the flower, ovate, hairy, membrance brownish, acute apex; sepals connate, ovate, cymbiform; petals lanceolate, acminate, hairy; corolla, rotate, hairy, stamens four, equal seeds homogeneous, colorless or black, three, ellipsoid (Figure 10: [42]

Habitat: Same habits are aforementioned as Anchusa milleri.

Location: Qaa, Lat 34.319337. Long 36.458013, Alt:727m. 9/ IV/2018. (Figure 18).

Phenology and Date of discovery: V-VI. 9/IV/2018.

Specimen and accession number in K. Addam Herbarium: 941889-001 (Figure 17j).

\section{Platanthera Holmboei H. Lindb. (Orchidaceae)}

Description: Etymology Named after J. Holmboe, Norwegian botanist (1880-1943). Type Cy (1942). Synonym P. chlorantha subsp. holmboei (H. LINDBERG Iii.) J.J. Wood, P. montana subsp. holmboei (H. Lindberg fil.) Strohle. Plant less robust, 15$40 \mathrm{~cm} ; 2(-3)$ medium basal leaves $6-18 \mathrm{~cm} \times 2-5 \mathrm{~cm}$, near erect to spreading, oblong-lanceolate, channelled, 4-6 small, bract-like 
cauline leaves; bracts broad, leaf-like, the lowest at least longer than the flowers; inflorescence lax (up to 25 entirely green small flowers), cylindrical, appearing narrow; flowers close to stem, entirely green or greenish-yellow; sepals $7-10 \mathrm{~mm}$ x $3-4 \mathrm{~mm}$, spreading, oval-obtuse; petals ovoid, together forming a hood 5-7mm long; lip 7-10 mm x 1.5-3 mm, narrowly tongue-shaped, pendant, sometimes slightly curved backwards at the tip; spur club-shaped, cylindrical, attenuated at the base, little or not at all flattened at tip; anther with housings of pollinia divergent, well parted at their base 9 (Figure 11) [43].

Habitat: Prefers growing in the shady moist places in rainy moist winter (annual rainfall rate $1300 \mathrm{~mm}$ ), semi dry summer, under the trees in dense Pine and Quercus woods hiding between big rocks at $950 \mathrm{~m}$.

Location: Mishmish. Lat 34.418417 Long 36.156667, Alt: 1050m (Figure 18).

Phenology and Date of discovery: V-VI. 12/V/2019.

Specimen and accession number in K. Addam Herbarium: 1251978-001 (Figure 17k)

\section{Potamogeton Perfoliatus L. (Potamogetonaceae)}

Description: Perennial aquatic plant arises in both standing and flowing freshwater habitats; stems up to $3 \mathrm{~m}$, round; leaves

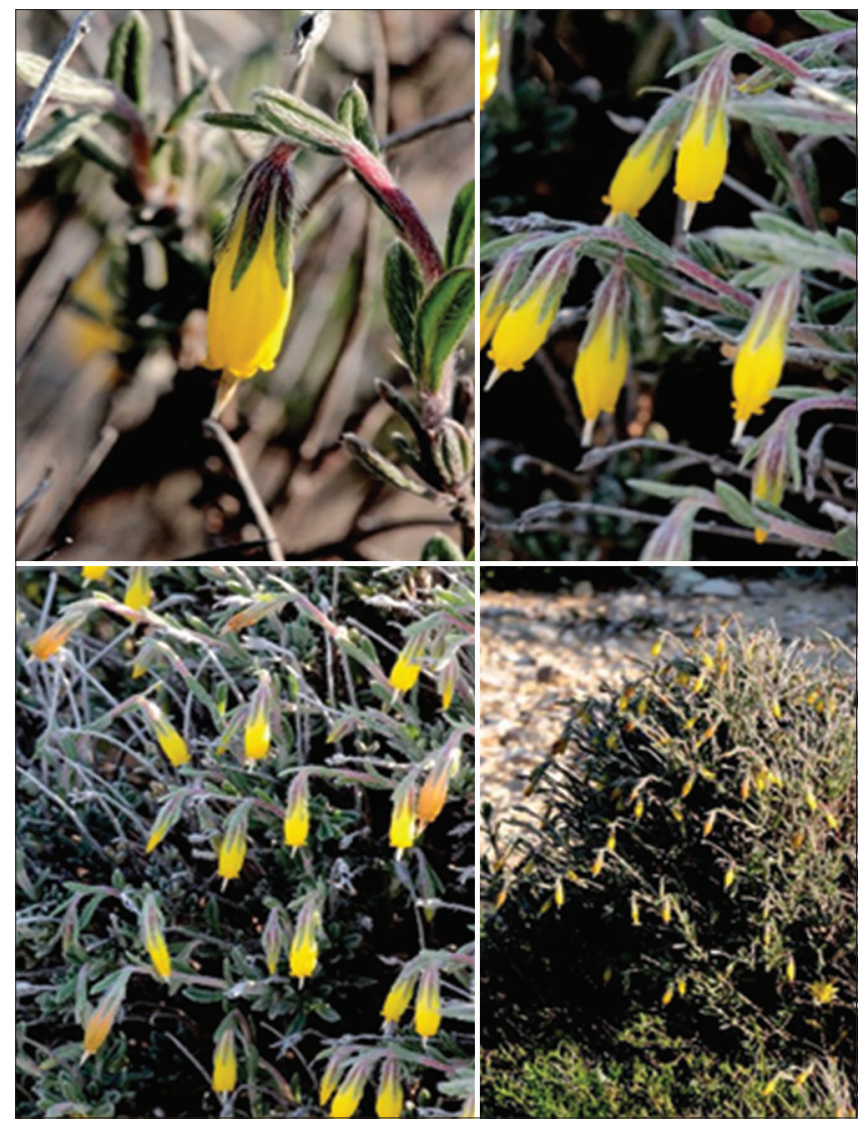

Figure 9: Onosma fruticosa
20-115 mm long, 7-42 mm wide, submerged (no floating leaves), translucent, oval, with no stalk, flat apex, veins (5-12) on either side of the midrib, undulating margins, vary considerably in color, might be dark green, bright green, yellowish, olive, brownish and red brown; Stipules, rather delicate, commonly fall off quite directly soon after the new leaf has unfurled; inflorescence, spike 1 to $2 \mathrm{~cm}$, short when in fruit, flowers small, green, on dense spikes up to $3 \mathrm{~cm}$ long at water surface; fruit 2.5 to $3 \mathrm{~cm}$, olive-green asmooth, semi-circular on the dorsal side and convex on the ventral; keel is faint with two lateral ridges on the dorsal side, beak is very short; rhizome, creeping, robust, sporadically (Figure 12) [44,45,46].

Habitat: Grows in the wetlands of Lebanon. They have the richest biodiversity of habitats of all semi desert habitats (low rain and hot summer), wide range of freshwater habitats including lakes, rivers and streams, large ponds and canals, and sufficient amounts of sun and water.

Location: Hawsh Ammiq, Lat 33.703582. Long 35.81148, Alt: $863 \mathrm{~m}$. (Figure 18).

Phenology and Date of discovery: 18/VIII/2018.

Specimen and accession number in K. Addam Herbarium:1881897-001 (Figure 17).

\section{Quercus Libani G. Olivier. (Fagaceae)}

Description: Deciduous tree 7 - 8 (10) m, (sometimes less than $3 \mathrm{~m}$ ); leaf 4-10 x 2-3 cm, slender, oval-lanceolate, elongated to lanceolate, sharp serrations, base rounded, apex pointed, dark radiant green adaxially, paler slightly pubescent beneath (in the adult state the leaf's upper side is dark green and the underside is pale green), 10-16 vein pairs, each ending in a long acuminate tooth; petiole $0.6-1 \mathrm{~cm}$, golden-yellow, slender, monoecious (individual flowers are either male or female, but both sexes can be found on the same plant and is pollinated by wind); fruit, acorn $2 \mathrm{~cm}$, peduncle short, thick, enclosed 3/4 by cup; cup thick with long, recurved, tomentose scales, maturing in 2 years; basal scar flat or convex; Bark large, twigs and buds bark dark grey with orangey colored furrows; twigs olive brown, rough, lentiocellate; buds red brown, scaly (Figure 13) [47].

Habitat: The climate of the area is depicted by cold winters with frequent precipitation as snow (annual rainfall rate $1200 \mathrm{~mm}$ ), rigorous summers with extended physiological drought, prefers full sun, on slightly acidic to alkaline, rocky

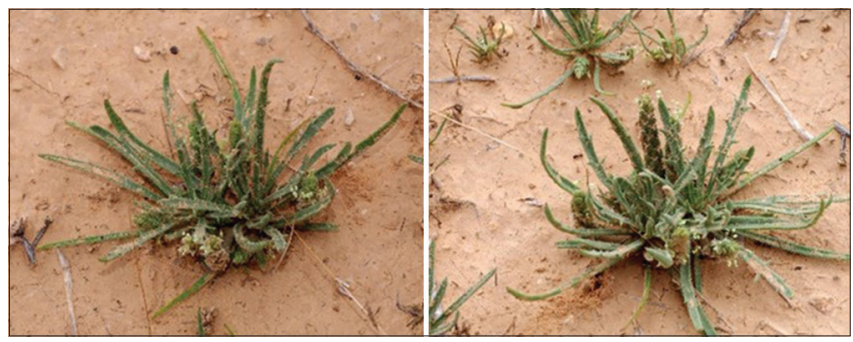

Figure 10: Plantago crypsoides 
mountains, an open rocky places in tough environmental conditions.

Location: Jabal Mresti, Lat 33.61986. Long 35.667282, Alt: 1742m (Figure 18).

Phenology and Date of discovery: 14/X/2018.
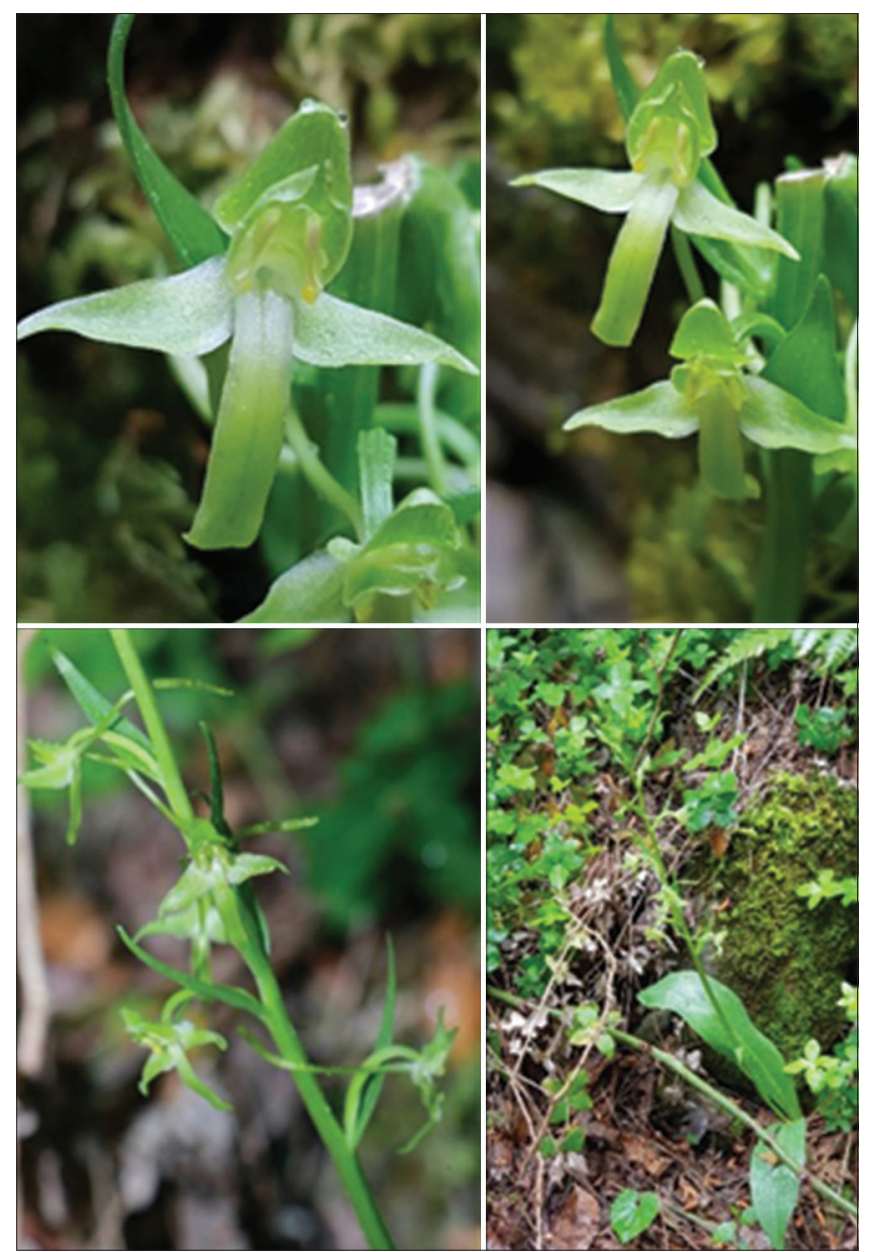

Figure 11: Platanthera holmboei

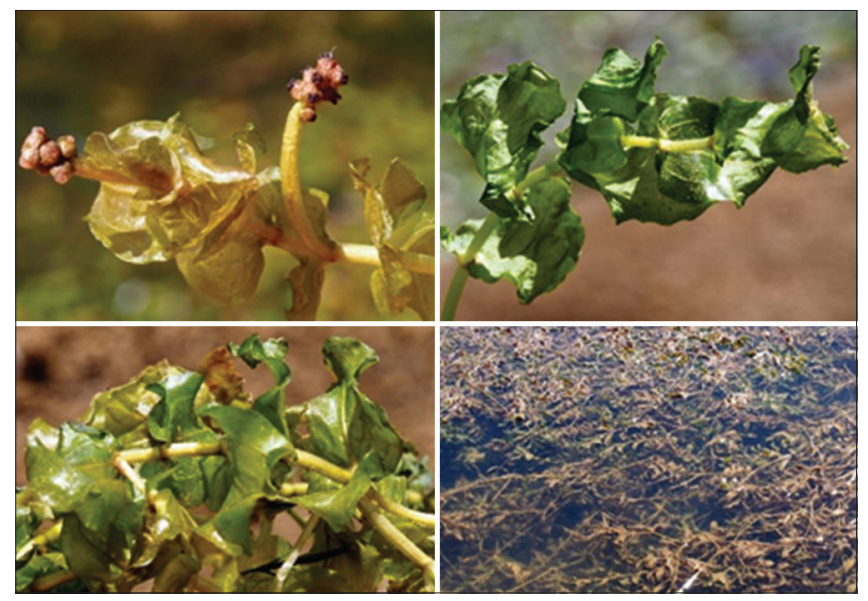

Figure 12: Potamogeton perfoliatus
Specimen and accession number in K. Addam Herbarium: 14101851-001 (Figure 17m).

\section{Rhamnus Kurdica Boiss. \& Hohen. (Rhamnaceae)}

Description: Shrub 1-3 m, tortuous-velvety branches, at the end thorny; leaves pale green, leathery, short, pubescent-tomentose, ovate or oblong-spatulate, obtuse or acute, larger than in other species and generally wider (1-3 cm. Instead of 1-2), crenate or denticulate, sometimes with very little blackish glands at the insertion of the teeth; flowers in small numbers, axillary, fasciculate, on pedicels matching them, pubescent; fruit obovate with furrow covered with a cartilaginous rim; drupe as large as marrow fat pea, mottled, groove of seed bifid (Figure 14) [48].

Habitat: Same aforementioned habitats as Anchusa in addition to Rhamnus kurdica, thrive at high rocky mountains between big rocks whereby these trees are challengingly unreachable.

Location: Ras Baalbek, Lat 34.256609. Long 36.426647, Alt: $1061 \mathrm{~m}$. (Figure 18).

Phenology and Date of discovery: 21/IX/2017.

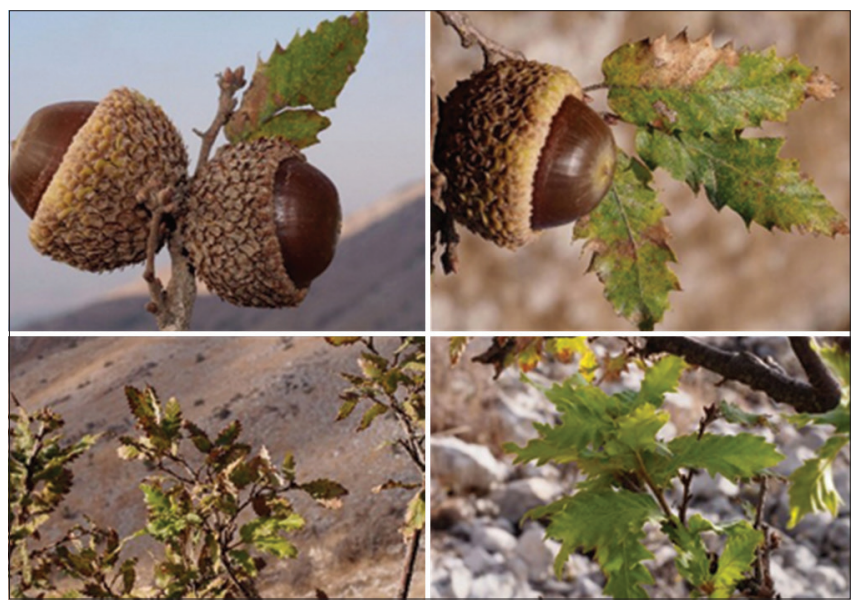

Figure 13: Quercus libani

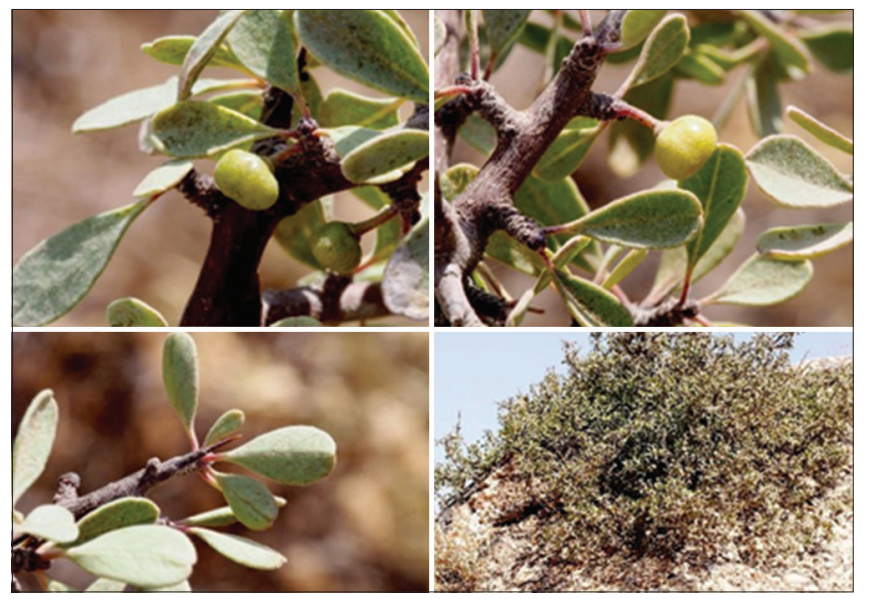

Figure 14: Rhamnus kurdica 
Specimen and accession number in K. Addam Herbarium: 21917104-001 (Figure 17n).

\section{Tulipa Biflora Pall. (Liliaceae)}

Description: Perennial bulbous plant; bulb ovoid, slightly elongate apically, $1-1.5 \mathrm{~cm}$ in diam.; tunic brown, woollypubescent inside distally; stem $10-15 \mathrm{~cm}$, regularly glabrous; leaves two, spaced, linear, not overtopping; flower 5-10 mm wide, margin crisped; flowers solitary or paired, barely more; tepals milky white, bright yellow at base, oblong to lanceolate, 2--2.5 cm $\times 6--12 \mathrm{~mm}$; outer ones abaxially tinted with yellowish green or purplish green; inner ones longitudinally marked with yellowish green or purplish green at center, hairy at base. Inner stamens somewhat longer than outer ones; filaments dilated proximally, hairy at base; style ca. $1 \mathrm{~mm}$.; Capsule subglobose, ca. $1.5 \mathrm{~cm}$ in diam (Figure 15) [49].

Habitat: Heavy snow and rainy moist winter (annual rainfall rate $1000 \mathrm{~mm}$ ) and fall, dry summer, on slightly acidic to alkaline rocky mountains. It prefers open rocky places in obstinate environmental conditions.

Location: Makmel (Above Aainata), Lat 34.1882. Long 36.038846, Alt: 2470m. (Figure 18).

Phenology and Date of discovery: IV-VI. 8/V/2017.

Specimen and accession number in K. Addam Herbarium: 851765-001 (Figure 17o).

\section{Xanthium Strumarium Subsp. Sibiricum (Patrin ex Widder) Greuter. (Asteraceae)}

Description: Annual, invasive, medical plant; stem $20-90 \mathrm{~cm}$, branched or simple, falling forwards; leaves alternate, entire, oblanceolate to oblong, covered by short hairs and long bristles, smooth margin, obscurely three lobed or toothed, obtuse to acute apex, base attenuate, sessile upper leaves; inflorescence, leafy, raceme-like, and lax in fruit; hermaphrodite; flowers, bracteate, and pedicellate; bracts, sessile, foliose; pedicel 3-8 $\mathrm{mm}$ with elongate fruit; calyx $5-7 \mathrm{~mm}$ splitted approximately to base; lobes, linear, not accrescent in fruit; corolla $1-1.3 \mathrm{~cm}$, pinkish or white; tube 7-9 $\mathrm{mm}$ straight with scales $0.5 \mathrm{~mm}$ interpolated at the corolla-throat, exserted, velutinous, oblong, tips are curved outwards, limb $4-5 \mathrm{~mm}$ broad, zygomorphic slightly; lobes $1.5-2 \mathrm{~mm}$, obovate broadly; stamens interpolated at the center of the tube, in two series of 2 and 3; anthers 1 $\mathrm{mm}$, oblong- elliptic, obtuse; ovary glabrous; style 2-2.5 mm, slender, glabrouss; stigma two-lobed; fruit, four pods; four nutlets 3.5-4 x 2-2.5 mm, erect or somewhat oblique; flat inner face, convex outer face, and reticulate-ribbed; ribs glabrous, smooth, yellowish-brown (Figure 16: [50].

Habitat: Same habits as aforementioned Anchusa milleri.

Location: Yammouneh, Lat 34.115873 Long 36.02769 Alt:1361m. (Figure 18).

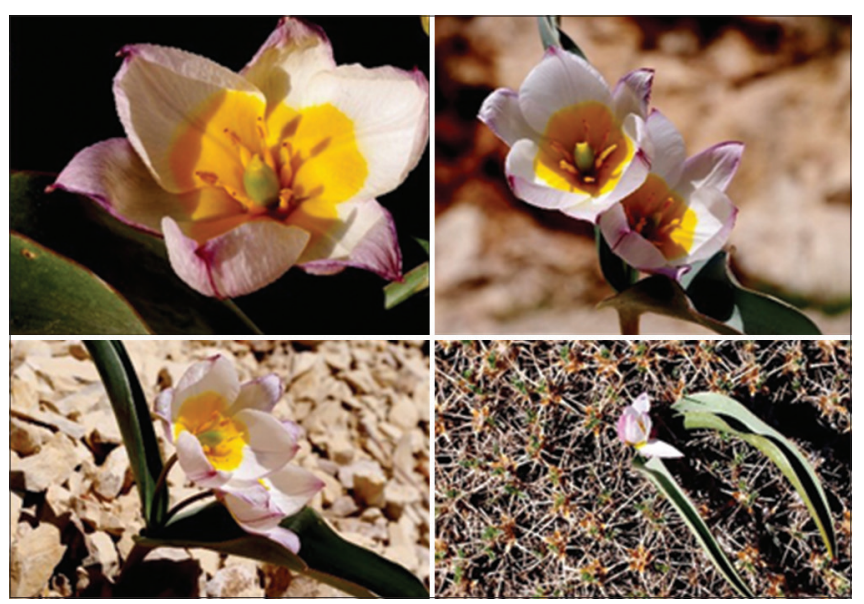

Figure 15: Tulipa biflora
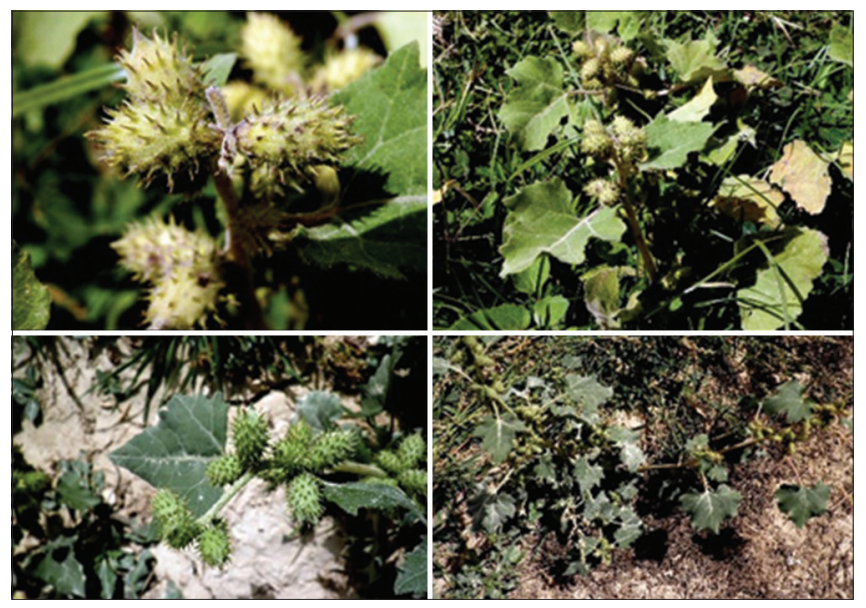

Figure 16: Xanthium strumarium subsp. sibiricum.

Phenology and Date of discovery: VIII- IX; 11/IX/2018.

Specimen and accession number in K. Addam Herbarium: 1191816-001 (Figure 17p).

\section{DISCUSSION}

Most of the species found are very sporadic in Lebanon and some of them are even added to the red list (Hypericum olivieri (Spach) Boiss., Plantago crypsoides Boiss., Quercus libani G. Olivier) [51, 52]. Quercus libani was found in the Cedar Wood of Ain Zhalta in 2015 and in Mount Mresty in 2018 at an altitude of $1600-1800 \mathrm{~m}$. Its presence in Lebanon was mentioned according to G Post in both Cedar Woods of Barouk and Ain Zhalta in 1932 [13]. Since then, no one had acknowledged or mentioned anything about its existence in the country. As for Moterde who could not find it in Lebanon in his 35 years of fieldwork in Lebanon, we wonder how it was called Libani and he found it only in the North Lattakia forest in Syria [15]. We wonder how he could not find it for 35 years of fieldwork even though it was easy to find in these places which were pointed out by Post.It was very difficult to discover Rhamnus kurdica Boiss. \& Hohen due to the struggles to reach it at high altitudes (1061 m) and treacherous rocky mountains at Ras Baalbek since it favors 


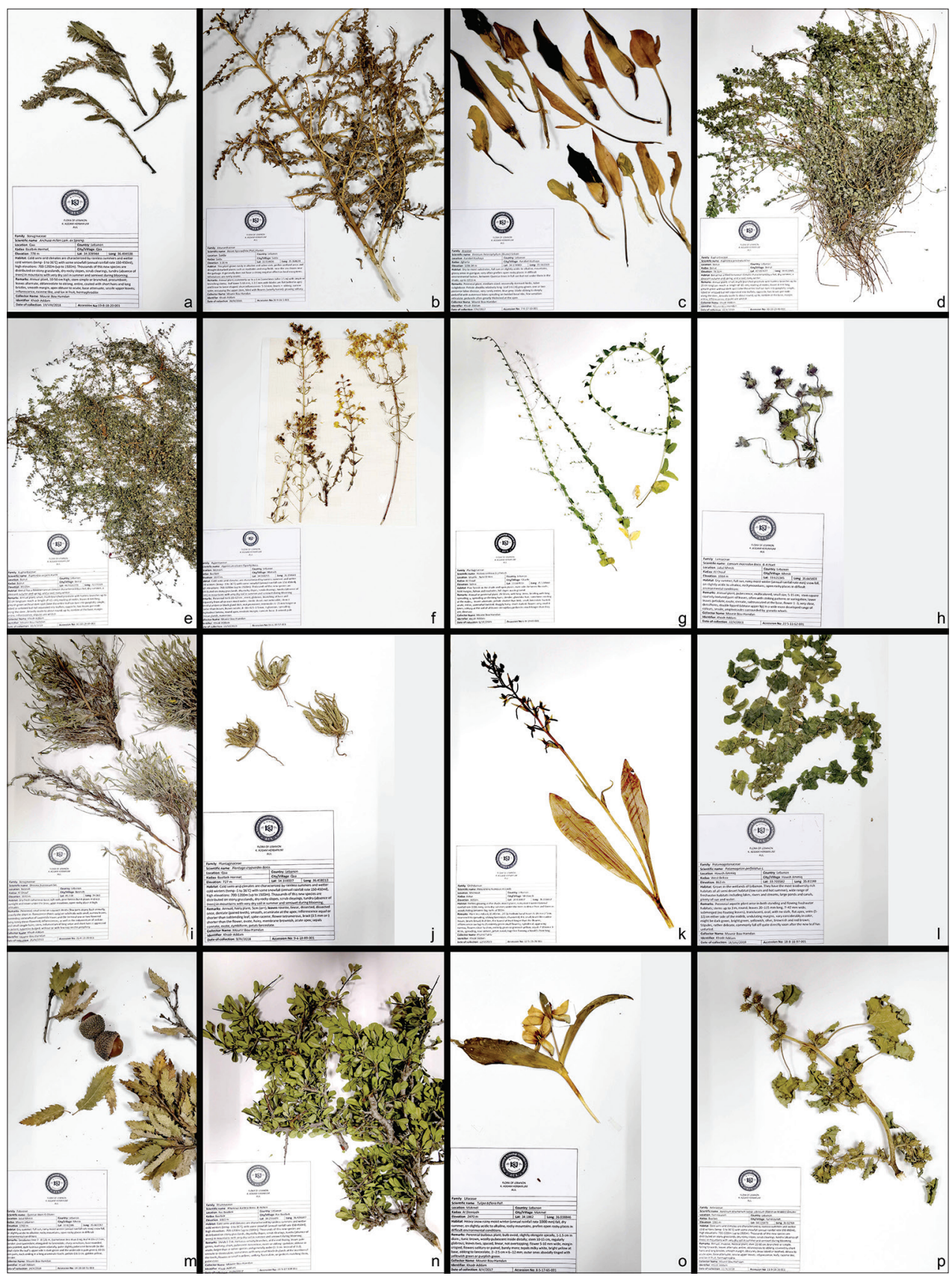

Figure 17: (a-c) Voucher Specimens of all the new species deposited in K. Addam's Herbarium Arts, Sciences and Technology University in Lebanon

to grow between the rocks as if it is getting out of them and in semi desert climate. Post mentioned that it was found at Anti-Lebanon Mountains in 1933 [13], but he did not pinpoint whether its place is in the Lebanese part or Syrian part of this chain. Mouterde did not find it at all. So, if post found it in the Syrian part, then we will be the first scientists that announce its existence in Lebanon for the first time. Hypericum olivieri was found for the first time by Spach and called Eremosporum olivieri [53]. In 1867, Boissier E. classified it as Hypericum olivieri (Spach) Boiss. and this is its scientific and accepted authorship name [54]. Hypericum olivieri is a very occasional flora and has not been recorded in Lebanon by any author before. Mouterde mentioned that it existed in Syria but not in
Lebanon. Hypericum olivieri is a very infrequent flora in Lebanon and needs to be safeguarded. We think it is threatened because of urbanism. Onosma fruticosa is considered an endemic flora to Cyprus [55]. It was found in Lebanon seven years ago (2013) in a small village called Botmeh in Mont Lebanon. We searched during these seven years for it hoping that it might be found at other places in Lebanon but couldn't, so we decided finally to publish it. More than hundred Onosma fruticosa were found to flourish in this place outstandingly side by side with Saturea thymbra. Even before these seven years, we thought that it was Saturea till we recognized it in its blossoming period with its mind-blowing attractive flower of different colors like white, yellow and yellowish orange. Plantago crypsoides Boiss Near 


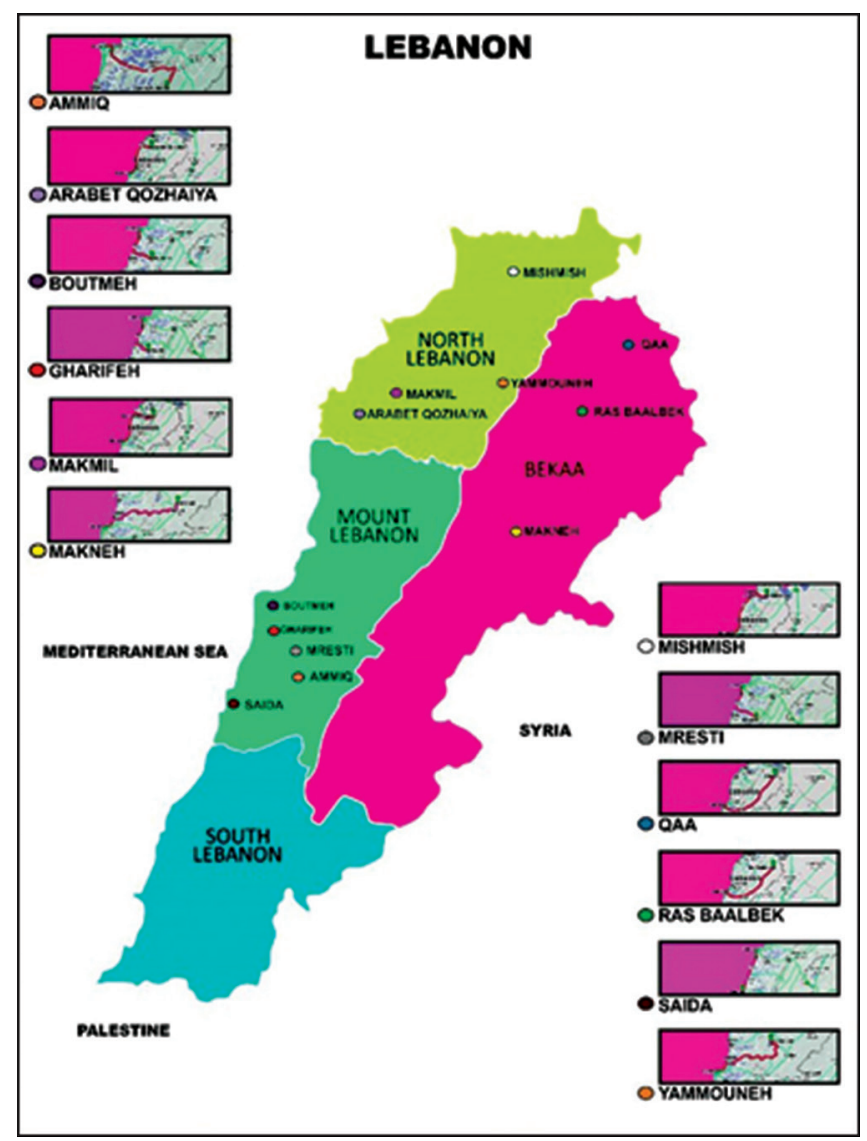

Figure 18: Location of new species found in Lebanon.

endemic species were recorded in the Western Mediterranean coastal sand dunes [56].

\section{CONCLUSION}

Anchusa milleri, Bassia hyssopifolia, Eminium heterophyllum (Blume) Schott., Euphorbia prostrata Aiton, Euphorbia serpens Kunth, Hypericum olivieri (Spach) Boiss., Kickxia cirrhosa (L.) Fritsch., Lamium macrodon Boiss. \& A. Huet, Onosma fruticosum Sm. lder, Plantago crypsoides Boiss., Platanthera holmboei H. Lindb., Potamogeton perfoliatus L., Rhamnus kurdica Boiss. \& Hohen., Tulipa biflora Pall., and Xanthium strumarium subsp. sibiricum (Patrin ex Widder) Greuter. were discovered, identified, and examined for their taxonomic, morphological and phenological attributes and added to the Lebanese flora for the first time with the exception of Quercus libani G. Olivier that was not found even by Mouterde but was mentioned by Post in 1914. Illustrated floral tracing, more than 20 years of fieldwork, and about 10 years of observation, phenology, a host of locations, and the existence of numerous quantities of the new sixteen species recognized the confirmation for the existence of these new records. The voucher specimen (representative dried sample) of the plant was deposited in K. Addam Herbarium in Arts, Sciences and Technology University in Lebanon and was collected and identified by Dr. K. Addam and Mr. M. Bou-Hamdan.

\section{Recommendations}

The recent loss of biodiversity as well as a plethora of other factors have put 50,000 plant species at a global eminent risk of extinction. Conserving at-risk species is often complicated by covariance or non-additivity among threats, which makes it challenging to establish optimal management strategies. We sought to demographically measure covariance and nonadditive impacts of more risks on more infrequent plant species than ever endeavoured in Lebanon [57]. Perhaps the widespread destruction of habitat is the utmost threat that faces many species. Scientists worldwide assure that the best way to safeguard the endangered species is to protect the distinctive places where they thrive. Wild plants need places that secure their needs of nutrients and appropriate territories to organize the germination of the new breed systematically. Logging, over-grazing, and development all result in habitat destruction. Therefore, special attention should be addressed to the cattle's overgrazing which leads to the extinction of these rare flora. Moreover, a continuous observation of the number, blossoming, and scarcity of these flora must be considered to acknowledge the reasons behind their extinction. By supporting the protection of wildlife habitat, whole communities of plants in parks, wildlife refuges, and other open spaces that are great places to visit and enjoy are safeguarded [58]. A host of actions must be emphasized and fortified in order to support the reverse of the trend politically, technically, and financially. Fortunately, some of our novel records are still existent and are present securely because of the following circumstances:

a. The presence of tremendously austere environmental conditions as they grow in highly mountainous territories and rocky terrains

b. The presence of distant mountain landscapes which make the access strenuous

c. The menacing political situations specifically reaching the Syrian borders where the war is in action

d. The absence of ecotourism as well as sports and touristic activities

\section{Measurements}

a. Raising awareness by introducing educational and social events, news jacking, and distributing brochures. These awareness campaigns would be accessible for the general public and villagers precisely to hinder fires that might occur because of the garbage thrown by people in these mountains.

b. Emphasizing the importance of utilizing dedicated research about the new records in this rural area because of its copiousness [23].

\section{ACKNOWLEDGMENTS}

The team would like to thank Miss. Joumana Itani for her assistance in drawing the illustrations as well as all those who assisted us in the success of this publication. The team would also like to thank Mr. Khaled Taleb who found and showed us Platanthera holmboei H. Lindb. Special thanks to Ass. Prof. Jean Stefan LU (Lebanese University) and Prof. Ghassan Ibrahim DU (Damascus University) for their academic cooperation. 


\section{REFERENCES}

1. Al-Mayah AA, Al-Asadi WM, Al-Knaany ST. Six New Specific Records to the Flora of Basrah, Iraq. Biological and Applied Environmental Research. 2020, Vol. 4 (1): 18-24

2. Myers N. The biodiversity challenge: expanded hot-spots analysis. Environmentalist. 1990 Dec 1;10(4):243-56.

3. Quézel P. Definition of the Mediterranean region and the origin of its flora. Geobotany. In plant conservation in the Mediterranean area (ed. C. Gomez- campo). 1985. PP 9-24.

4. Hegazy A, Doust JL. Plant ecology in the Middle East. Oxford University Press; 2016; PP 23.

5. Addam K, Sabbagh N, Bou-Hamdan M, Mohammad H, Hout k, Ophrys holoserica (Burm. f.) Greuter subsp. Shoufensis subsp. novo K. Addam \& M. Bou-Hamdan (ORCHIDACEAE), A new world record from Lebanon. International Journal of Botany Studies. 2018; Vol 3(6):25-23

6. Addam K, Mohamad H, Bou Hamdan M, Takkoush J, Rifai F. Cyclamen persicum f. puniceum (Gleason) GreyWilson: New Plant Record Joined the Lebanese Flora. International Journal of Botany Studies. 2017; 2(4): 12-15.

7. Addam $\mathrm{K}$, Al-Zein MS, Bou-Hamdan $\mathrm{M}$, Naous $\mathrm{H}$. A new record: cyclamen persicum mill. var. autumnale grey-wilson was added to the native Lebanese Flora. American Scientific Research Journal for Engineering, Technology, and Sciences (ASRJETS). 2016;26(4):186-94.

8. UNDP / MOE / ECODIT (2011) State and Trends of the Lebanese Environment

9. Ministry of Environment (Republic of Lebanon). Fifth National Report of Lebanon: To the Convention on Biological Diversity. 2015. PP15-16.

10. Lebanon Sate of the Environment Report Ministry of Environment/LEDO Chapter 10. Biodiversity \& Natural Heritage ECODIT. 2001; PP 145.

11. Addam K. Crocus baalbekensis K. Addam \& M. Bou Hamdan sp. Nov and its three forms (IRIDACEAE), new endemic species and forms from Lebanon, joined the Lebanese Flora. MOJ Eco Environ Sci. 2019;4(2):75-83

12. Addam K, Kebbe I, Takkoush J, Hout K. A New Variety from Lebanon, Ophrys Apifera Var. Libanotica K. Addam and M. Bou-Hamdan (Orchidaceae). 2015; 6(1):39-46.

13. Post GE. Flora of Syria, Palestine and Sinai.1933;2:524.

14. Tohmé G, Tohmé H. Illustrated flora of Lebanon, second edition. Beirut: CNRS Lebanon publications, 2014.

15. Mouterde P. Nouvelle flore du Liban et de la Syrie: Texte [et] atlas. Dar-el Machreq Editeurs; 1966

16. Haber RM, Semaan-Haber M. Floral enchantment to Lebanon. The authors; 2009.

17. Addam K, Sabbagh N, Bou-Hamdan M, Itani J, Jamaleddine K. Phytogeography, population, habitat, ecology, threat and conservation action of Orchis anatolica Boiss. in Lebanon. 2018; 4:34-46.

18. Addam K, Kebbe I, Bou-Hamdan M, Hout K. Neotinea tridentata var. libanotica (Orchidaceae), A New Variety from Lebanon. 2014; 5(1):35-38

19. Ophrys Omegaifera Subsp. Gharifensis (Orchidaceae), A New Subspecies from Lebanon. Journal of Botanical Research. 2013; $4(1): 25-27$.

20. Addam K, Girgis E, Bou-Hamdan M, Makkouk M, Naous H. Five Records Added to the Lebanese Native Orchids: Ophrys Omegaifera Subsp. Algarvensis, Basilissa, Fleischmanii, Vasonica and Ophrys Polycratis (Orchidaceae). Journal of Ecology and Environmental Sciences. 2016b; 7(3):180-185.

21. Addam K, Takkoush J, Bou-Hamdan M, Itani J. Five Established Orchids Ophrys Apifera Var. Chlorantha, Aurita, Purpurea, Purpurea. F. Alba. and Flavescens (Orchidaceae) in Lebanon as Part of the Native Flora. Journal of Ecology and Environmental Sciences. 2015b; 6(2):163-169.

22. Addam K, Kebbe I, Takkoush J, Hout K. A New Variety from Lebanon, Ophrys Apifera Var. Libanotica K. Addam and M. Bou-Hamdan (Orchidaceae). 2015a; 6(1):39-46.

23. Addam K. New ten varieties and five subspecies of crocus baalbekensis K. Addam \& M. Bou-Hamdan (Iridaceae) endemic to Lebanon added to the Lebanese flora. MOJ Eco Environ Sci. 2019;4(6):281-94.

24. Addam K. New ten varieties and five subspecies of crocus baalbekensis K. Addam \& M. Bou-Hamdan (Iridaceae) endemic to Lebanon added to the Lebanese flora. MOJ Eco Environ Sci.
2019;4(6):281-94

25. Addam K. Orchis troodi (Renz) P. Delforge, Orchis sitiaca (Renz) P. Delforge and Orchis Anatolia subsp. albiflora Subsp. Novo K. Addam \& M. Bou-Hamdan, Three New Rare Orchids Joined the Lebanese Flora. International Journal of Botany Studies. 2017b. 2017;2(6):221-8.

26. Sprengel KP. Der botanische Garten der Universität zu Halle im Jahre 1799. Bei CA Kümmel; 1800.

27. Chu GL, Sanderson SC. The genus Kochia (Chenopodiaceae) in North America. Madroño. 2008 Oct;55(4):251-7.

28. Hefner M, Kratsch HA. Nevada Nuisance Weed Field Guide. University of Nevada Cooperative Extension; 2018; pp76.

29. Lobin W, Boyce P. Eminium koenenianum (Araceae), a new species from NE Turkey and a key to the genus Eminium. Willdenowia. 1991 Feb 28:43-51.

30. Madhani H, Rabeler R, Pirani A, Oxelman B, Heubl G, Zarre S. Untangling phylogenetic patterns and taxonomic confusion in tribe Caryophylleae (Caryophyllaceae) with special focus on generic boundaries. Taxon. 2018 Feb;67(1):83-112

31. Burkill, H.M.The useful plants of West Tropical Africa. 2nd Edition. Vol. 2. Families E-I. Royal Botanic Gardens, Kew, Richmond, United Kingdom. 1994; PP 636

32. Carter, S. \& Leach, L.C. Euphorbiaceae, subfamily Euphorbioideae, tribe Euphorbieae. In: Pope, G.V. (Editor). Flora Zambesiaca. Vol 9 part 5. Royal Botanic Gardens, Kew, Richmond, United Kingdom. 2001; PP 339-465.

33. Dibble AC. New England Wild Flower Society's Flora Novae Angliae: A Manual for the Identification of Native and Naturalized Higher Vascular Plants of New England. Rhodora. 2012 Jul;114(959):337-40.

34. Horn JW, van Ee BW, Morawetz JJ, Riina R, Steinmann VW, Berry PE, Wurdack KJ. Phylogenetics and the evolution of major structural characters in the giant genus Euphorbia L.(Euphorbiaceae). Molecular Phylogenetics and Evolution. 2012 May 1;63(2):305-26.

35. Wolf M, Király G. Euphorbia serpens (Euphorbiaceae), a new alien species in Hungary. Acta Botanica Hungarica. 2014 Feb $25 ; 56(1-2): 243-50$

36. Robson NK. Studies in the genus Hypericum L (Hypericaceae) 5 (2). Sections 17. Hirtella to 19. Coridium. Phytotaxa. 2013 May $14: 4(1): 127-258$

37. Grey-Wilson C, Blamey M. Mediterranean wild flowers: a complete guide to the flowers of Mediterranean coasts and islands, native and introduced]. Harper Collins; 1993. PP 413.

38. Mouterde P. Nouvelle flore du Liban et de la Syrie: Texte [et] atlas vol. 3. Dar-el Machreq Editeurs; 1966; PP 139

39. RHS A-Z encyclopedia of garden plants. United Kingdom: Dorling Kindersley. 2008. PP 1136

40. Wedgwood, Hensleigh.On False Etymologies. Transactions of the Philological Society. 1855;6: 70.

41. Teppner H. Notes on morphology and karyology of Onosma fruticosa (Boraginaceae-Lithospermeae) from Cyprus. In PHYTON-ANNALES REI BOTANICAE 2012;52(2):301-320.

42. Höpke J, Mucina L, Albach DC. Phylogenetic and morphometric analysis of Plantago section Coronopus (Plantaginaceae). Taxon. 2019; 68(2):315-39.

43. Delforge P. Orchids of Europe, North Africa and the Middle East Timber Press; 2006; PP 144.

44. Rose F. The Wild Flower Key. Frederick Warne \& Co. 2006. PP 491-492.

45. Kaplan Z, Jarolimova V, Fehrer J. Revision of chromosome numbers of Potamogetonaceae: a new basis for taxonomic and evolutionary implications. Preslia. 2013;85(4):421-82.

46. COLES A. PRESTON, CD. Pondweeds of Great Britain and Ireland (BSBI Handbook No. 8). Botanical Society of the British Isles, London: 1995, reprinted 1996.

47. Seigue A. forêt circumméditerranéenne et ses problèmes. Maisonneuve et Larose; 1985.Seigue A. forêt circumméditerranéenne et ses problèmes. Maisonneuve et Larose; 1985. PP 119-502.

48. Post, GE. Flora of Syria, Palestine and Sinai: a handbook of the flowering plants and ferns, native and naturalized from the Taurus to Ras Muhammad and from the Mediterranean Sea to the Syrian desert. 2nd ed. Vol. 2. PP 291 Beirut. American Press.

49. Wu, Z. Y. \& P. H. Raven, eds. Flora of China. Vol. 24 (Flagellariaceae through Marantaceae). Science Press, Beijing, and Missouri Botanical Garden Press, St. Louis. 2000; PP 123-126.

50. A.J.C Grierson \& D.G.Long. Flora of Bhutan. Published by RoB and RBGE. 2001. 
51. Stephan, J. 2018. Quercus libani . The IUCN Red List of Threatened Species 2018: e.T194187A2303417. https://dx.doi.org/10.2305/IUCN. UK.2018-1.RLTS.T194187A2303417.en. Downloaded on 02 March 2020.

52. Schembri PJ, Sultana J, editors. Red data book for the Maltese Islands. Valletta, Malta: Department of Information; 1989; PP 32.

53. Spach E., Histoire Naturelle des Végétaux. 1836;5:375.

54. Boissier E. Flora Orientalis: Thalamiflorae. apud H. Georg. 1867;1:803.

55. Hand R, Hadjikyriakou G. N., Christodoulou C. S. Updated numbers of the vascular flora of Cyprus including the endemism rate. Cypricola.
2019;13:1-6

56. Ahmed DA, Shaltout KH, Kamal SA. Mediterranean sand dunes in Egypt: Threatened habitat and endangered flora. Life Science Journal. 2014;11(10):946-56.

57. Bernardo HL, Goad R, Vitt P, Knight TM. Nonadditive effects among threats on rare plant species. Conservation biology: the journal of the Society for Conservation Biology. 2019 Nov 24.

58. https://www.endangered.org/10-easy-things-you-can-do-to-saveendangered-species/ 